Expl Agric. (2019), volume 55 (S1), pp. 252-274 (C) Cambridge University Press 2017. This is an Open Access article, distributed under the terms of the Creative Commons Attribution licence (http://creativecommons.org/licenses/by/4.0/), which permits unrestricted re-use, distribution, and reproduction in any medium, provided the original work is properly cited.

doi:10.1017/S0014479716000788

\title{
STRUGTURED STAKEHOLDER ENGAGEMENT LEADS TO DEVELOPMENT OF MORE DIVERSE AND INGLUSIVE AGROFORESTRY OPTIONS
}

\author{
By EMILIE SMITH DUMONT $\dagger \ddagger \S$, SUBIRA BONHOMME $\dagger$, \\ TIMOTHY F. PAGELLA $\ddagger$ and FERGUS LLOYD SINGLAIR $\dagger \ddagger$ \\ †World Agroforestry Centre (ICRAF), United Nations Avenue, Gigiri, PO Box 30677-00100, \\ Nairobi, Kenya and $\ddagger$ School of the Environment and Natural Resources, Bangor University, Bangor, \\ Groynedd, LL57 2DG, UK
}

(Accepted 28 November 2016; First published online 30 January 2017)

\begin{abstract}
SUMMARY
There is a lot of interest in the contribution that agroforestry can make to reverse land degradation and create resilient multifunctional landscapes that provide a range of socio-economic benefits. The agroforestry research agenda has been characterized by approaches that promote a few priority tree species, within a restricted set of technological packages. These have often not spread widely beyond project sites, because they fail to take account of fine scale variation in farmer circumstances. New methods are needed to generate diverse sets of agroforestry options that can reconcile production and conservation objectives and embrace varying local conditions across large scaling domains. Here, we document a novel approach that couples local knowledge acquisition with structured stakeholder engagement to build an inclusive way of designing agroforestry options. We applied this approach in the eastern part of the Democratic Republic of Congo (DRC) where armed conflict, erratic governance and poverty have resulted in severe pressure on forests in the Virunga National Park, a global biodiversity hotspot. Around the park, natural resources and land are severely degraded, whereas most reforestation interventions have consisted of exotic monocultures dominated by Eucalyptus species grown as energy or timber woodlots mainly by male farmers with sufficient land to allocate some exclusively to trees. We found that structured stakeholder engagement led to a quick identification of a much greater diversity of trees (more than 70 species) to be recommended for use within varied field, farm and landscape niches, serving the interests of a much greater diversity of people, including women and marginalized groups. The process also identified key interventions to improve the enabling environment required to scale up the adoption of agroforestry. These included improving access to quality tree planting material, capacity strengthening within the largely nongovernmental extension system, and collective action to support value capture from agroforestry products, through processing and market interventions. Integrating local and global scientific knowledge, coupled with facilitating broad-based stakeholder participation, resulted in shifting from reliance on a few priority tree species to promoting tree diversity across the Virunga landscape that could underpin more productive and resilient livelihoods. The approach is relevant for scaling up agroforestry more generally.
\end{abstract}

\section{INTRODUCTION}

The current global environmental crisis is leading to calls for new strategies to sustainably manage agricultural landscapes so that they can provide a more balanced set of provisioning, regulating, supporting, and cultural ecosystem services (MA,

§Corresponding author. Email: e.smith@cgiar.org 
2005). Land use systems that promote multi-functionality, such as agroforestry, are seen as potential vehicles to deliver resilience at landscape scale and play an important role in the ecological restoration of degraded land (Mbow et al., 2014). Farmers make decisions about land use change locally and the factors influencing their decisions are largely context specific, determined by a complex mix of biophysical and socioecological conditions, as well as by the enabling policy and institutional environment (Coe et al., 2014). Most agroforestry development and research projects have, in the past, focused on promoting prescriptive technology packages, such as improved fallows, alley cropping or fodder banks (Pollini, 2009), whereas tree selection has been largely based on the prioritization of a few selected species for domestication or promotion (Franzel et al., 1996). Despite the promise of agroforestry technologies, reviews of adoption have highlighted their often limited spread beyond project sites (Meijer et al., 2015). Where adoption has been widespread, it has often been restricted to a narrow group of stakeholders, such as those with higher resource endowment and secure land tenure. Women, for example, have frequently been less likely to utilize agroforestry technologies, limiting the socio-economic benefits that are realised (Kiptot and Franzel, 2012). A separate but related issue is that agroforestry and reforestation projects in Africa have often led to the promotion of a few largely exotic tree species (Ashley et al., 2006). This can have detrimental impacts on biodiversity and contributes to ever more simplified agroecosystems (Harvey et al., 2011). This is especially critical in areas around the protected tropical forest (DeFries et al., 2007).

There are now calls for different approaches to agroforestry promotion that go beyond prescriptive 'one size fits all' agroforestry technology designs and that promote only a few iconic agroforestry tree species (Coe et al., 2014). It is argued that more diverse and adaptable technology options will be adopted by more people and deliver greater benefits both to smallholder livelihoods and to ecosystem health (Franzel et al., 2001). Tree management options that can be locally adapted to fine scale variation in both ecological and socio-economic context are likely to spread further and faster than less flexible prescriptions. The contextual variables that condition suitability of agroforestry options depend on which factors are important for a particular innovation to be adopted, and how much these factors vary across the geography of interest. Common ecological contextual variables that need to be considered include various soil parameters, altitude, climate and water availability, whereas variations in socio-economic context include, ethnic differences, gender roles, assets and access to (Coe et al., 2014; Reubens et al., 2011). There is a scope for new approaches to promoting agroforestry that look at farming systems and landscapes more holistically than previously, in order to analyse variations in context and offer farmers a broader menu of agroforestry options suited to their different sets of needs and circumstances (Franzel et al., 2001; German et al., 2006).

The objectives of the research reported here were to explore the extent to which greater involvement of stakeholders and their knowledge in designing agroforestry interventions would lead to more diverse and inclusive options being identified for promotion, together with developing an understanding of how the resulting options could be tailored to local context. We tried out this structured stakeholder engagement 
in the challenging context of the landscape around the Virunga National Park in the East of the Democratic Republic of Congo (DRG). This is a global biodiversity hotspot that has been subject to prolonged environmental degradation and conflict. Over the past three decades, there have been various reforestation initiatives attempting to promote tree planting to reduce the pressure on natural forests. These have focused on the promotion of energy woodlots, using a few fast growing exotic species, managed mostly by men who have large enough holdings to devote some land exclusively to trees (Lejeune et al., 2013). We adopted a participatory action research approach (Chevalier and Buckles, 2013), working closely with development and conservation partners, in particular, the World Wide Fund for Nature (WWF), a key regional actor involved in promoting energy woodlots on farms since 1987.

\section{METHODOLOGY}

\section{Site description}

The Virunga National Park is located in North Kivu province in the East of the DRC stretching along the Ugandan and Rwandese borders at the heart of the Great lakes (Figure 1). It embraces a land area of $59483 \mathrm{~km}^{-2}$ with a population estimated in 2015 as 6.655 million and belongs to the biodiversity hotspot of the Albertine rift (INS, 2015). The region is ecologically diverse, with altitude varying from $800 \mathrm{~m}$ in the equatorial forests and river plains to $2500 \mathrm{~m}$ in the Afromontane forest zone with summits peaking above $5000 \mathrm{~m}$ in the Rwenzori glaciers, with sharp gradients that have given rise to a wide range of habitat types, including savannas, equatorial lowland and Afromontane forests (Plumptre et al., 2007).

The province, in general, is endowed with fertile volcanic soils and a favourable tropical climate but with more pronounced ecological variation in the northern part of the province. Agriculture used to be the engine of a thriving economy with dynamic domestic and international trade in a range of food and industrial crops. This collapsed in the 1990s with the proliferation of local-level rebellions and international armed conflict causing a prolonged humanitarian and environmental crisis. In this densely populated part of the world, with an overall provincial average of 112 people $\mathrm{km}^{-2}$, conflict has caused an increase in urbanization and markedly unequal access to farmland (INS, 2015; Jayne et al., 2014). The main land use around the park continues to be agriculture, involving annual and perennial crops as well as large cattle ranches. Current trends are towards increasing reliance on subsistence rather than commercial farming, loss of soil fertility and decreasing crop yields.

There are ethnic differences between the northern and southern parts of the study area. The Nande are the predominant ethnic group in the northern part around Beni and Lubero, whereas the southern part is more ethnically diverse and subject to severe civil conflicts between Hunde, Tembo and Nyanga communities and a large migrant population of Banyarwanda. Indigenous Batwa people have been displaced from protected forest areas, including the Virunga National Park, and are a particularly marginalised group (Gilbert, 2013). Most communities are reliant for their survival on natural resources and especially protected forests, which are now under severe 


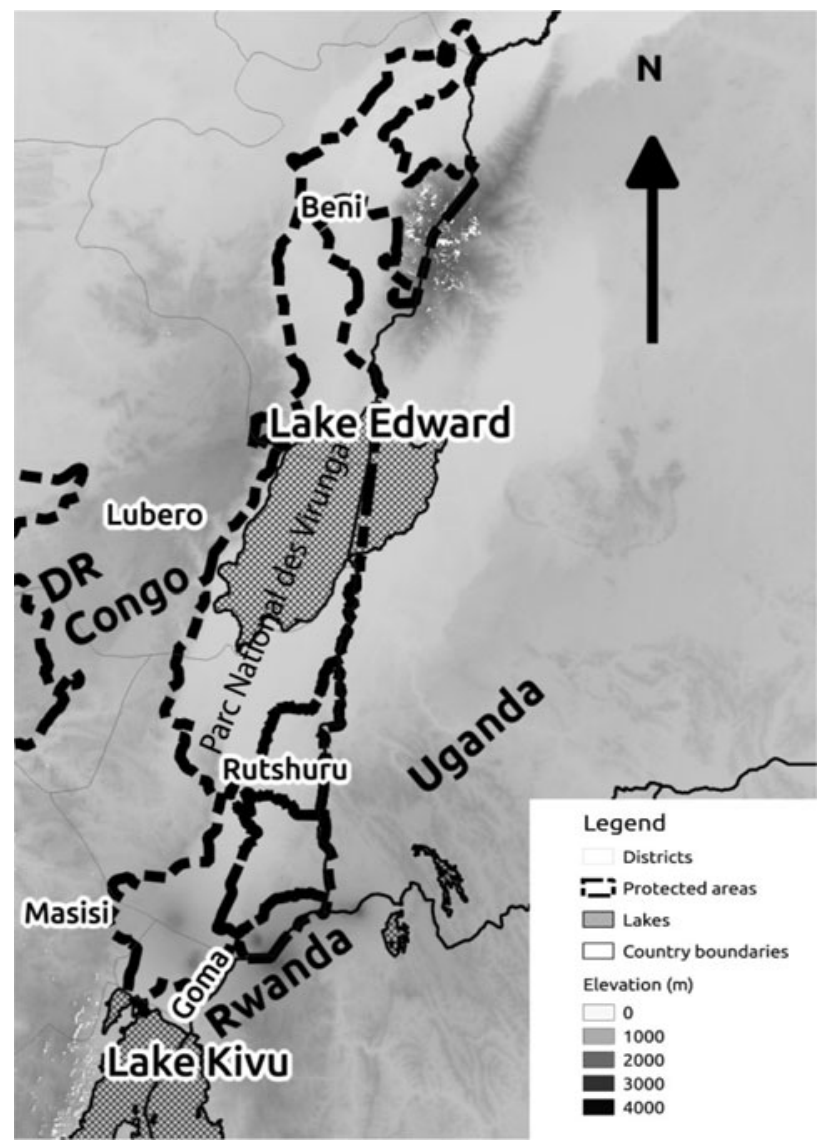

Figure 1. Map of the Virunga landscape in North Kivu, Eastern DRC with elevation information and the Parc National des Virunga boundaries (map by B. Onkware).

pressure because of illegal charcoal production (Lejeune et al., 2013). The baseline in terms of agroforestry development in the region was a focus on promoting fast growing exotic tree species for the production of charcoal or timber in woodlots, largely dominated by the Eucalyptus genus but also including Acacia mearnsii and Senna siamea and to a lesser extent Grevillea robusta (LeJeune et al., 2013), with a main aim of reducing pressure on resources from the Park. Our key conservation and development partner in the research was WWF who had been implementing the ECOmakala project that focused on woodlot promotion, for 7 years before the present research began.

\section{Local knowledge acquisition}

Decision making about agroforestry at a landscape scale in the North Kivu province is hampered by the sparse literature and data available about local agricultural and land use practices. In order to capture information about prevailing 
livelihood systems, tree management in various farm and landscape niches and farmers' knowledge and preferences relating to trees, two participatory scoping studies were conducted in the Lubero district in the north and the Masisi district in the south. The aim was to elicit local knowledge about drivers of land use and land cover change as well as about agroforestry practices and the present and potential roles of trees in supporting people's livelihoods. Semi-structured interviews were conducted with 60 individual farmers (of which 22 were women) complemented by 10 focus group discussions with farmer association members and forestry technicians involving a further 85 people (25 of them women). These field studies were instrumental in enabling the facilitation of stakeholder workshops by researchers, because they provided a collective understanding of the prevailing land use and livelihood systems in the area and helped to build trust between researchers and other local stakeholders. Where appropriate, information from the scoping study was used to set up and structure discussion sessions in the subsequent multi-stakeholder design workshops.

\section{Multi-stakeholder design workshops}

Two multi-stakeholder design workshops were organized, one in Goma covering the three districts in the southern part of the province (Masisi, Rutshuru and Nyaragongo) and the other in Butembo covering two districts in the northern part (Lubero and Beni) in October 2014. Participants were selected on the basis of their involvement and interest in tree planting in the region and included a diversity of interest groups with different types of knowledge (practical, technical and scientific). Many of the participants were drawn from those who had taken part in the earlier scoping studies. There were 25 participants in the Goma workshop (five of them women) and 38 in Butembo (eight of them women). They included technical staff and members of farmers' tree planting associations involved in the ECOmakala project, government extension agents, representatives of different farmers groups (herders, coffee growers, beekeepers) and women's community-based organisations, and lecturers in local technical colleges and universities.

The objective of the workshop sessions was to explore agroforestry options potentially suitable for the different contexts found across the province. This was achieved by addressing four themes that each constituted a working group: (1) trees and crops; (2) trees and livestock; (3) trees and income and (4) trees and gender (which involved all the women participants). The main steps followed during the workshop were (i) an introduction led by the workshop facilitators that covered agroforestry practices around the world and presented results from the local knowledge acquisition activity in North Kivu; (ii) identification by participants of a list of generic agroforestry practices with supplementary details of tree species, farm niche locations and spatial arrangements potentially involved in different locations; (iii) assessment of opportunities and constraints to the adoption of these practices; and, (iv) definition of actions to promote agroforestry locally and address barriers to adoption. Following this, we systematized and represented the contextual information affecting adoption of agroforestry practices including requirements for interventions to create 
a conducive enabling environment (Coe et al., 2014). Priority actions to address barriers to the adoption of promising agroforestry practices were then identified by participants.

\section{Training and reflection}

A technical manual incorporating agroforestry options suitable for different contexts across North Kivu was developed, incorporating findings from the design workshops, together with scientific knowledge about the tree species and agroforestry practices involved (Smith Dumont et al., 2015). This manual was used in training, involving 2 events with 58 participants that included WWF forestry outreach staff, technical staff from community-based organisations, governmental agents and local researchers over an 18 month period following the design workshops and culminating in a reflection workshop that sought to collate and reflect upon experiences of participants who had taken part in the structured stakeholder engagement. The workshop was held in Goma between the 21 and 23rd March 2016 March and brought together 46 people from the southern and northern parts of the province

RESULTS

\section{Generic agroforestry practices}

Three major types of land with different prospects for agroforestry were identified during the scoping as separate land use categories (Sinclair, 1999), within which trees may be integrated. These were cropland, pastures and homesteads, and they were used as an organising framework for discussing integration of trees in fields, on farms and across landscapes in the scoping study and stakeholder workshops. Fifteen generic types of agroforestry practice relevant to these different land use categories were identified during the workshops (Table 1). This variety reflects the diversity of needs and opportunities across the North Kivu province. These practices were generic (in that they describe primarily the desired function). In our experience, local actors will customise these agroforestry systems (by using different mixtures of trees) to better suit the ecological requirements of their location, embracing the altitudinal gradient across the province, as well as farmers' individual needs, endowments and preferences.

\section{Tree species}

During the workshops, stakeholders detailed 15 agroforestry technology options. Participants were able to associate a range of tree species with these agroforestry practices across a range of farm and landscape niches. These niches were more detailed than the land use categories described in Table 1 and provided more precise detail on the location of practices within farms. During the workshops 71 species of trees, shrubs and liana (Appendix 1) were identified as suitable for use in at least one of the generic agroforestry practices. Forty-four species were discussed during the South Virunga workshop and 57 in the Butembo workshop with 34 species common to both. Five of the 15 options developed by stakeholders illustrate not only the potential diversity of native and exotic trees they considered appropriate for each option, but 
Table 1. Generic agroforestry practices identified in the two stakeholder workshops in North Kivu province.

\begin{tabular}{|c|c|c|}
\hline Generic agroforestry practice & Land use category & Remarks \\
\hline Woodlot & Cropland*, pastures, homestead & $\begin{array}{l}\text { For timber, energy, bee keeping, } \\
\text { medicine, and mushrooms, may be } \\
\text { zoned (a separate larger area of } \\
\text { woodlot }>0.25 \text { ha) or clumped } \\
\text { (groups of trees }<025 \text { ha) }\end{array}$ \\
\hline Live-fence & Cropland, pastures, homestead & Generally multipurpose tree species. \\
\hline $\begin{array}{l}\text { Boundary planting of high value } \\
\text { trees }\end{array}$ & Cropland, pastures, homestead & \\
\hline Fodder bank & Cropland, pastures, homestead & $\begin{array}{l}\text { May be clumped, on boundaries or } \\
\text { along contours }\end{array}$ \\
\hline Trees for veterinary or biopesticides & Cropland, pastures, homestead & $\begin{array}{l}\text { Only in the northern part of the } \\
\text { province. }\end{array}$ \\
\hline Scattered high value trees & Cropland, pastures & Mainly for timber and fruit. \\
\hline Improved fallow & Cropland, pastures & \\
\hline Trees for erosion control on slopes & Cropland, pastures & $\begin{array}{l}\text { In degraded zones and along } \\
\text { contours or on terraces. }\end{array}$ \\
\hline Trees for river bank stabilisation & Cropland, pastures & \\
\hline Scattered shade trees & Cropland, pastures & $\begin{array}{l}\text { On perennial cropland where the } \\
\text { crop is coffee, cocoa or banana) } \\
\text { may also be along boundaries }\end{array}$ \\
\hline Trees for soil improvement & Cropland, pastures & $\begin{array}{l}\text { Generally multipurpose tree species. } \\
\text { May be on boundaries or } \\
\text { scattered/intercropped. }\end{array}$ \\
\hline Windbreak & Pastures & \\
\hline Orchard & Cropland & Mainly fruit trees with bee keeping. \\
\hline Trees for condiments and food & Homestead & $\begin{array}{l}\text { Especially Laurus nobilis and Moringa } \\
\quad \text { oleifera }\end{array}$ \\
\hline Medicinal trees & Homestead & \\
\hline
\end{tabular}

*Cropland includes both annual and perennial crops.

also the range of farm niches and potential spatial arrangements, corresponding to different farm conditions and people's needs (Table 2). Planting high value fruit trees, for example, is a key option to improve nutrition and income, and these can be integrated in several landscape and farm niches. Other options were more niche specific, such as integrating shade trees in coffee systems.

\section{Options by context matrices}

To understand contextual variables influencing the adoption and scaling up of agroforestry options across the province, we compiled information relating to opportunities and constraints associated with the different options identified by participants into two matrices covering farm level (Table 3) and enabling environment (Table 4) contextual requirements, respectively. We present details for three of the five agroforestry options outlined in Table 2 to illustrate the results obtained when participants were asked to discuss the contextual relevance of different options.

Workshop participants identified 13 contextual factors that were important in determining suitability of different options. These were classified by researchers into 
Table 2. Five locally specified agroforestry technology options for North Kivu province.

\begin{tabular}{|c|c|c|c|}
\hline \multirow[b]{2}{*}{ Agroforestry option } & \multirow[b]{2}{*}{ Tree species } & \multicolumn{2}{|c|}{ Farm or landscape niche } \\
\hline & & Generic agroforestry practices & Position in landscape \\
\hline $\begin{array}{l}\text { High value fruit trees to } \\
\text { improve nutrition and } \\
\text { income }\end{array}$ & $\begin{array}{l}\text { NATIVE: Annona senegalensis; Cola nitida; Syzigium spp.; Myrianthus } \\
\text { spp.- EXOTIC: Averrhoa carambola; Carica papaya; Citrus spp.; } \\
\text { Cyphomandra betacea; Eriobotrya japonica; Mangifeira indica; Morus alba; } \\
\text { Passiflora spp.; Persea americana; Psidium guajava; Syzygium malaccense }\end{array}$ & $\begin{array}{l}\text { Orchard } \\
\text { Scattered high value trees } \\
\text { Boundary planting of high value trees }\end{array}$ & $\begin{array}{l}\text { Annual cropland } \\
\text { Pastures } \\
\text { Riverbanks } \\
\text { Homestead } \\
\text { Perennial cropland }\end{array}$ \\
\hline $\begin{array}{l}\text { Trees for soil fertility } \\
\text { improvements and erosion } \\
\text { control }\end{array}$ & $\begin{array}{l}\text { NATIVE: Albizia gummifera; Cordia abyssinica; Croton megalocarpus; } \\
\text { Erythrina abyssinica; Ficus spp.; Maesopsis eminï; Maesa lanceolata; } \\
\text { Markhamia lutea; Sesbania sesban; Spathodea campanulata; Tephrosia } \\
\text { vogelii - Tetradenia riparia EXOTIC: Acacia mearnsï; Acrocarpus } \\
\text { fraxinifolius; Cajanus cajan; Calliandra calothyrsus; Casuarina equisetifolia; } \\
\text { Cedrela spp; Flemingia macrophylla; Gliricidia sepium; Leucaena } \\
\text { leucocephala; Grevillea robusta; Moringa oleifera;Morus alba; Senna } \\
\text { siamea; Senna spectabilis; Tithonia diversifolia }\end{array}$ & $\begin{array}{l}\text { Trees for erosion control on slopes } \\
\text { (contours, and degraded zones). } \\
\text { Trees for soil improvement } \\
\text { (boundary, intercropped). }\end{array}$ & $\begin{array}{l}\text { Annual cropland } \\
\text { (maize, cassava, } \\
\text { beans, sweet } \\
\text { potatoes, Irish } \\
\text { potatoes) }\end{array}$ \\
\hline Fodder banks & $\begin{array}{l}\text { NATIVE: Albizia gummifera; Ficus spp.; Erythrina abyssinica; Maesa } \\
\text { lanceolata; Myrianthus arboreus; Sesbania sesban; Sinarundanaria alpina; } \\
\text { Tephrosia vogeliii; EXOTIC: Acacia mearnsii; Cajanus cajan; Calliandra } \\
\text { calothyrsus; Leucaena leucocephala; Persea americana; Moringa oleifera; } \\
\text { Tithonia diversifolia }\end{array}$ & $\begin{array}{l}\text { Fodder bank (clumped or along } \\
\text { boundaries, or contours) }\end{array}$ & $\begin{array}{l}\text { Pastures Homestead } \\
\text { Cropland }\end{array}$ \\
\hline Coffee agroforestry & $\begin{array}{l}\text { NATIVE: Albizzia gummifera; Cordia abyssinica; Erythrina abyssinica; Ficus } \\
\text { thonningii; Ficus vallis choudae; Kigelia africana; Maesopsis eminï; } \\
\text { Markhamia lutea; Sesbania sesban; Spathodea campanulata; Terminalia } \\
\text { superba- EXOTIC: Acacia mearnsii; Cedrela spp.; Leucaena leucocephala; } \\
\text { Grevillea robusta; Persea americana }\end{array}$ & $\begin{array}{l}\text { Scattered shade trees (intercropped } \\
\text { or on boundaries) }\end{array}$ & $\begin{array}{l}\text { Perennial cropland } \\
\text { (coffee fields). }\end{array}$ \\
\hline Woodlots & $\begin{array}{l}\text { NATIVE: Cordia abyssinica; Entandrophragma excelsum; Maesopsis eminï; } \\
\text { Markhamia lutea; Podocapus falcatus; Prunus africana EXOTIC: Acacia } \\
\text { mearnsii; Eucalyptus spp.; Grevillea robusta; Cedrela spp.; Senna siamea; } \\
\text { Terminalia superba }\end{array}$ & Woodlots (zoned or clumped) & $\begin{array}{l}\text { Cropland (particularly } \\
\text { upper slope, } \\
\text { degraded land and } \\
\text { riverbanks) }\end{array}$ \\
\hline
\end{tabular}


Table 3. Farm level contextual factors and requirements for three agroforestry options documented from stakeholder engagement for the Virunga landscape.

\begin{tabular}{|c|c|c|c|c|c|c|}
\hline \multirow[b]{2}{*}{ Agroforestry option } & \multicolumn{6}{|c|}{ Farm level contextual requirements } \\
\hline & Ecology & $\begin{array}{l}\text { Availability of germ } \\
\text { plasm }\end{array}$ & $\begin{array}{l}\text { Farm size and } \\
\text { location }\end{array}$ & Labour availability & Land tenure & Gender \\
\hline $\begin{array}{l}\text { High value fruit trees to } \\
\text { improve nutrition and } \\
\text { income } \\
\text { LOCAL RELEVANGE } \\
\text { Fruit trees have largely } \\
\text { disappeared as a result of } \\
\text { conflict and insecurity } \\
\text { aggravating problems with } \\
\text { food and nutritional } \\
\text { security }\end{array}$ & $\begin{array}{l}\text { Regional climate is } \\
\text { overall favourable } \\
\text { to a diversity of } \\
\text { species but some } \\
\text { species are better } \\
\text { suited to particular } \\
\text { elevations e.g., } \\
\text { Mangifeira indica, } \\
\text { Carica papaya and } \\
\text { Citrus spp at lower } \\
\text { altitude and } \\
\text { Cyphomandra betacea } \\
\text { at higher altitude. }\end{array}$ & $\begin{array}{l}\text { Improved germ plasm } \\
\text { is not widely } \\
\text { available. And } \\
\text { grafting is not a } \\
\text { widely held skill. } \\
\text { There is potential } \\
\text { to use existing } \\
\text { nursery network to } \\
\text { develop fruit tree } \\
\text { seedling market. } \\
\text { Mother trees are } \\
\text { present in the } \\
\text { landscape }\end{array}$ & $\begin{array}{l}\text { Along field } \\
\text { boundaries on } \\
\text { small farms }(<1 \\
\text { ha)-in orchards on } \\
\text { larger holdings. } \\
\text { Only viable where } \\
\text { distance from field } \\
\text { or pastures to } \\
\text { homestead is close } \\
\text { enough to mitigate } \\
\text { threat of fruit theft. } \\
\text { Bush fire is a threat } \\
\text { in lowlands. }\end{array}$ & $\begin{array}{l}\text { There is intensive } \\
\text { labour requirement } \\
\text { especially for } \\
\text { weeding during tree } \\
\text { establishment. } \\
\text { Understanding } \\
\text { about labour } \\
\text { availability was } \\
\text { limited but there } \\
\text { were many } \\
\text { women-headed } \\
\text { households with a } \\
\text { few family } \\
\text { members active in } \\
\text { agriculture. }\end{array}$ & $\begin{array}{l}\text { Land security is a } \\
\text { prerequisite and } \\
\text { women have } \\
\text { restricted access to } \\
\text { land. Early } \\
\text { maturing trees } \\
\text { preferable for } \\
\text { households with } \\
\text { lower security of } \\
\text { tenure. Potential for } \\
\text { community } \\
\text { orchards on land } \\
\text { given to community } \\
\text { associations. }\end{array}$ & $\begin{array}{l}\text { Women control } \\
\text { income from fruit } \\
\text { sales. Orchards can } \\
\text { provide benefits to } \\
\text { men and women } \\
\text { through the } \\
\text { integration of bee } \\
\text { keeping where men } \\
\text { control income } \\
\text { from honey } \\
\text { production. }\end{array}$ \\
\hline
\end{tabular}


Table 3. continued

\begin{tabular}{|c|c|c|c|c|c|c|}
\hline \multirow[b]{2}{*}{ Agroforestry option } & \multicolumn{6}{|c|}{ Farm level contextual requirements } \\
\hline & Ecology & $\begin{array}{l}\text { Availability of germ } \\
\text { plasm }\end{array}$ & $\begin{array}{l}\text { Farm size and } \\
\text { location }\end{array}$ & Labour availability & Land tenure & Gender \\
\hline $\begin{array}{l}\text { Fodder banks } \\
\text { LOCAL RELEVANCE } \\
\text { Diversify feed sources } \\
\text { especially in dry season for } \\
\text { specialist, dairy and mixed } \\
\text { livestock, farmers. Trees } \\
\text { can be multi-purpose and } \\
\text { so also help to improve soil } \\
\text { fertility and provide other } \\
\text { products. }\end{array}$ & $\begin{array}{l}\text { Many leguminous } \\
\text { species are } \\
\text { adaptable to most } \\
\text { altitudes in the } \\
\text { landscape but some } \\
\text { have specific } \\
\text { altitudinal ranges } \\
\text { (e.g., Calliandra } \\
\text { calothyrsus < 1800 } \\
\text { m; Maesa lanceolate < } \\
\text { 1500 m; Dombeya } \\
\text { spp 1800-3000 } \\
\text { masl; Sinarundinaria } \\
\text { alpina 2300-3300 } \\
\text { masl }\end{array}$ & $\begin{array}{l}\text { Lack of seedling } \\
\text { availability through } \\
\text { nurseries. Native } \\
\text { fodder species are } \\
\text { not domesticated. } \\
\text { Some native species } \\
\text { can be propagated } \\
\text { from cuttings. }\end{array}$ & $\begin{array}{l}\text { Zoned configuration } \\
\text { makes it suitable for } \\
\text { small farms and } \\
\text { homesteads even in } \\
\text { urban areas where } \\
\text { may be very small } \\
\text { constituting a } \\
\text { live-fence. Less } \\
\text { suitable in large } \\
\text { pastures with large } \\
\text { conflicts in Masisi. }\end{array}$ & $\begin{array}{l}\text { Labour required for } \\
\text { establishment and } \\
\text { protection against } \\
\text { browsing especially } \\
\text { in a juvenile phase. }\end{array}$ & $\begin{array}{l}\text { Land tenure is a } \\
\text { restricting factor, } \\
\text { more severely the } \\
\text { longer the rotation } \\
\text { length. There is a } \\
\text { scope for } \\
\text { developing } \\
\text { agreements for } \\
\text { ownership of fast } \\
\text { growing species on } \\
\text { rented land. }\end{array}$ & $\begin{array}{l}\text { Men are usually } \\
\text { responsible for } \\
\text { dairy production } \\
\text { especially in } \\
\text { Masisi/Rutshuru, } \\
\text { women for small } \\
\text { ruminants. Women } \\
\text { can benefit from } \\
\text { stakes and firewood } \\
\text { by-products }\end{array}$ \\
\hline $\begin{array}{l}\text { Woodlots } \\
\text { LOCAL RELEVANCE } \\
\text { Income possible for men } \\
\text { from important markets for } \\
\text { timber, charcoal and fibre } \\
\text { (Acacia mearnsii), medicine } \\
\text { (Prunus Africana) and honey } \\
\text { if bees are integrated. }\end{array}$ & $\begin{array}{l}\text { Exotic species adapted } \\
\text { to most parts of the } \\
\text { landscape. High } \\
\text { value native species } \\
\text { have altitudinal } \\
\text { requirements (e.g., } \\
\text { Podocarpus falcatus } \\
\text { and Prunus africana } \\
\text { at higher altitude } \\
\text { and Milicia excelsa or } \\
\text { Khaya anthoteca at } \\
\text { lower altitudes. }\end{array}$ & $\begin{array}{l}\text { Some exotic species } \\
\text { (especially } \\
\text { eucalypts) are } \\
\text { widely available. } \\
\text { Seed and seedling } \\
\text { systems not } \\
\text { developed for } \\
\text { native species but } \\
\text { native mother trees } \\
\text { present. }\end{array}$ & $\begin{array}{l}\text { Large farm sizes } \\
\text { required restricted } \\
\text { to wealthier men. } \\
\text { There may be } \\
\text { potential to plant } \\
\text { on degraded land } \\
\text { although eucalypts } \\
\text { may cause } \\
\text { degradation if } \\
\text { planted on fertile } \\
\text { land. }\end{array}$ & $\begin{array}{l}\text { Labour for sowing } \\
\text { and weeding } \\
\text { required. }\end{array}$ & $\begin{array}{l}\text { Land tenure is a } \\
\text { restricting factor, } \\
\text { more severely the } \\
\text { longer the rotation } \\
\text { length. }\end{array}$ & $\begin{array}{c}\text { Men are generally the } \\
\text { main beneficiaries. }\end{array}$ \\
\hline
\end{tabular}


Table 4. Enabling environment contextual factors for three agroforestry options documented from stakeholder engagement for the Virunga landscape.

\begin{tabular}{|c|c|c|c|c|c|c|c|}
\hline \multirow[b]{2}{*}{ Agroforestry option } & \multicolumn{7}{|c|}{ Enabling environment contextual requirements } \\
\hline & Financial capital & Infrastructure & Social capital & Human capital & Access to markets & Policy/Institutions & Culture \\
\hline $\begin{array}{l}\text { High value fruit trees } \\
\text { to improve nutrition } \\
\text { and income }\end{array}$ & $\begin{array}{l}\text { Cash required to } \\
\text { purchase inputs } \\
\text { (pesticides, } \\
\text { processing } \\
\text { equipment) often } \\
\text { not available to } \\
\text { women who often } \\
\text { lack capital to } \\
\text { invest aggravated } \\
\text { by low access to } \\
\text { micro-credit. }\end{array}$ & $\begin{array}{l}\text { Lack of infrastructure } \\
\text { and equipment for } \\
\text { condition- } \\
\text { ing/storing or } \\
\text { processing fruits. } \\
\text { The poor state of } \\
\text { roads and } \\
\text { agricultural paths } \\
\text { make } \\
\text { transportation } \\
\text { access to markets } \\
\text { for perishable } \\
\text { goods difficult. } \\
\text { The lack of fruit } \\
\text { selling points. }\end{array}$ & $\begin{array}{l}\text { Presence of women's } \\
\text { groups/ } \\
\text { associations in } \\
\text { villages. Presence } \\
\text { of civil and } \\
\text { religious } \\
\text { associations. }\end{array}$ & $\begin{array}{l}\text { Widespread } \\
\text { knowledge of a } \\
\text { variety of species. } \\
\text { Women lack } \\
\text { technical skills to } \\
\text { improve fruit tree } \\
\text { production - they } \\
\text { are entrepreneurs } \\
\text { but lack } \\
\text { management and } \\
\text { accounting skills; } \\
\text { extension network } \\
\text { exists but lacks } \\
\text { qualified technical } \\
\text { staff }\end{array}$ & $\begin{array}{l}\text { Local markets for } \\
\text { fresh fruits and for } \\
\text { processed products } \\
\text { far from saturation } \\
\text { but better prices } \\
\text { possible where } \\
\text { product bulked } \\
\text { and transported to } \\
\text { urban markets } \\
\text { though collective } \\
\text { marketing rare. . } \\
\text { Factories for } \\
\text { processing guava } \\
\text { and tree tomatoes } \\
\text { are located in cities } \\
\text { like Beni and } \\
\text { Goma. }\end{array}$ & $\begin{array}{l}\text { The national } \\
\text { program of } \\
\text { agricultural } \\
\text { intensification with } \\
\text { a fruit tree } \\
\text { component. No } \\
\text { fruit tree seed } \\
\text { regulation. } \\
\text { Pluralistic legal } \\
\text { rules have caused } \\
\text { mass land } \\
\text { grabbing and } \\
\text { conversion to } \\
\text { pastures reducing } \\
\text { availability of } \\
\text { agricultural land. }\end{array}$ & $\begin{array}{l}\text { Some fruit trees } \\
\text { associated with } \\
\text { taboos in certain } \\
\text { localities. } \\
\text { Sensitisation } \\
\text { campaigns about } \\
\text { family nutrition } \\
\text { and fruits are } \\
\text { changing } \\
\text { perceptions. Fruit } \\
\text { theft is a threat } \\
\text { and not considered } \\
\text { a punishable crime } \\
\text { in villages. Bush } \\
\text { fires are culturally } \\
\text { acceptable but } \\
\text { need to be } \\
\text { controlled for tree } \\
\text { establishment to } \\
\text { viable in many } \\
\text { contexts. }\end{array}$ \\
\hline
\end{tabular}


Table 4. continued

\begin{tabular}{|c|c|c|c|c|c|c|c|}
\hline \multirow[b]{2}{*}{ Agroforestry option } & \multicolumn{7}{|c|}{ Enabling environment contextual requirements } \\
\hline & Financial capital & Infrastructure & Social capital & Human capital & Access to markets & Policy/Institutions & Culture \\
\hline Fodder banks & Not mentioned & Not mentioned & $\begin{array}{l}\text { Local farmers' } \\
\text { institutions } \\
\text { organisations, } \\
\text { Technical } \\
\text { institutes, } \\
\text { Women's } \\
\text { associations, and } \\
\text { Herder's } \\
\text { associations must } \\
\text { be targeted } \\
\text { directly. }\end{array}$ & $\begin{array}{l}\text { Widespread } \\
\text { knowledge } \\
\text { available about } \\
\text { native and exotic } \\
\text { fodder trees. } \\
\text { Knowledge gaps } \\
\text { about nutritive } \\
\text { value (fodder } \\
\text { quantity, quality, } \\
\text { timing, and diet } \\
\text { formulation). The } \\
\text { lack of techniques } \\
\text { and knowledge } \\
\text { about cut and } \\
\text { carry, zero grazing } \\
\text { systems and con- } \\
\text { servation/storage } \\
\text { of fodder. }\end{array}$ & $\begin{array}{l}\text { Currently, the market } \\
\text { for tree fodder is } \\
\text { not developed but } \\
\text { there is a potential } \\
\text { for development } \\
\text { especially in } \\
\text { peri-urban areas. }\end{array}$ & $\begin{array}{l}\text { The lack of capacity } \\
\text { of state extension } \\
\text { services in } \\
\text { livestock } \\
\text { production could } \\
\text { be addressed } \\
\text { through } \\
\text { addressing the lack } \\
\text { of policy related to } \\
\text { improved pasture } \\
\text { management and } \\
\text { animal nutrition. }\end{array}$ & $\begin{array}{l}\text { Lopping trees for } \\
\text { fodder is common } \\
\text { but fodder trees } \\
\text { are not well } \\
\text { integrated in } \\
\text { farming practice. } \\
\text { Herders not } \\
\text { commonly } \\
\text { involved in tree } \\
\text { planting programs. } \\
\text { Zero grazing is } \\
\text { uncommon. There } \\
\text { are negative } \\
\text { perceptions of } \\
\text { trees competing } \\
\text { for space with } \\
\text { pasture grasses } \\
\text { and crops. }\end{array}$ \\
\hline Woodlots & $\begin{array}{l}\text { Land set aside with } \\
\text { delayed } \\
\text { production } \\
\text { benefits may } \\
\text { constrain } \\
\text { investment. }\end{array}$ & $\begin{array}{l}\text { The poor state of } \\
\text { roads and } \\
\text { agricultural paths } \\
\text { make } \\
\text { transportation } \\
\text { difficult and } \\
\text { expensive. }\end{array}$ & $\begin{array}{l}\text { Active tree planting } \\
\text { associations with } \\
\text { seedling networks } \\
\text { present across } \\
\text { most of the } \\
\text { districts }\end{array}$ & $\begin{array}{l}\text { Widespread technical } \\
\text { knowledge about } \\
\text { woodlots. Lack of } \\
\text { knowledge about } \\
\text { integrating bee } \\
\text { keeping with } \\
\text { woodlots. Gaps in } \\
\text { knowledge about } \\
\text { propagating native } \\
\text { trees and in skills } \\
\text { for managing } \\
\text { multiple species } \\
\text { woodlots. }\end{array}$ & $\begin{array}{l}\text { Farmers are poorly } \\
\text { integrated in value } \\
\text { chains (honey, } \\
\text { charcoal, timber). } \\
\text { There is a lack of } \\
\text { collective action } \\
\text { for transportation } \\
\text { of products and } \\
\text { low bargaining } \\
\text { power since farm } \\
\text { gate prices are low. }\end{array}$ & $\begin{array}{l}\text { Land use plans } \\
\text { needed to identify } \\
\text { land for food crops } \\
\text { and for } \\
\text { reforestation. } \\
\text { Heavy taxation } \\
\text { (informal and } \\
\text { formal) creates } \\
\text { disincentives for } \\
\text { tree planting. }\end{array}$ & $\begin{array}{l}\text { Woodlots are } \\
\text { common features } \\
\text { but dominated by } \\
\text { a few exotic } \\
\text { species. Slow } \\
\text { growth rate of } \\
\text { native species is } \\
\text { often a constraint } \\
\text { to establishing } \\
\text { diversity. }\end{array}$ \\
\hline
\end{tabular}


those operating at the farm level (6), and those relating to the enabling environment, within which farms operate (7). These categories were found useful for structuring discussion but are to some extent subjective, and there are interactions amongst them. Land tenure, for example, is seen here to operate at a farm level, in as much as the tenure status of land affects what options farmers are prepared to practice on it, but tenure may also be affected by both formal (policy and institutions) and less formal (cultural) aspects of the enabling environment. Gender influences other contextual factors because of differential access to resources amongst men and women, but also directly influences choices of tree species and agroforestry options.

Workshop participants indicated that the ecological conditions across the province of North Kivu were highly variable and hence suitable for a wide range of trees but that altitude was a major factor determining the performance and suitability of individual species in particular locations (Table 3). Access to quality germ plasm was a constraining factor for the establishment of all three options, with the exception of Eucalyptus seeds for establishing woodlots, which were widely available. Sourcing seed or seedlings of native species was difficult, and although parent trees were often present in the landscape, they were seldom used to produce propagation material because of the lack of knowledge and skills to do so (see human capital in Table 4). Farm size influenced how much space could be used for establishing orchards or woodlots, but there were also specific planting arrangements tailored to small holdings such as boundary planting, live fences and scattered trees in fields. Labour availability constrained establishment of trees, especially in female-headed households with few family members active in agriculture. Land tenure was a particularly restricting factor for tree establishment because many small farmers did not have secure land titles, although farmers who rented land could grow fast growing tree species where agreement could be reached with landlords. There were clear gender differences in benefits accruing from different practices; women were primary beneficiaries of high value fruit trees, whereas men were usually in control of woodlots. Men were also in charge of fodder banks for dairy farms, though women responsible for small ruminants could also benefit from on farm tree fodder availability, whereas women were often responsible for fruit tree orchards that could be utilised by men for bee-keeping.

Financial capital restrictions were particularly important for women, who did not have the formal means to invest in tree seedlings and inputs for improving fruit production (Table 4). The lack of road infrastructure was a constraint, especially for transporting and marketing fresh perishable fruits, timber, charcoal and honey. In terms of social capital, there were several local community-based organisations and tree planting associations. In terms of human capital, farmers and extension workers had knowledge about a wide range of trees and their suitability for different locations but lacked skills in propagating most native species. Women also lacked fruit tree management and propagation skills, and there were no trained extension staff specialised in horticulture to support them in this respect. Herders lacked knowledge about the nutritional value of fodder species and the conservation, management and handling of fodder from trees. Despite the market potential, notably to supply 
to urban areas, lack of collective action around wood and non-wood products was limiting value capture and hence profit. Women were particularly interested in value addition, including processing of fruits into juices or jams but lacked access to microfinance to enable them to engage in these opportunities. There were cross cutting policy issues that related mainly to pluralistic land tenure laws and customary rules that have allowed widespread alienation of land held under custom (Vlassenroot and Huggins, 2005), aggravated by the lack of government support in agricultural services and in land use planning. There were also cultural norms that affected the use of some tree species and the adoption or management of some practices. These included taboos around fruit trees as well as a lack of awareness that fruit consumption could improve nutrition, and ethnic and gender specificity in preferences for some tree species and practices, such as Batwa men favouring meliferous tree species to enhance bee-keeping.

\section{Delivery mechanisms for promoting agroforestry options}

Amongst solutions and contextual prerequisites for scaling up the three agroforestry practices documented in Tables 3 and 4, local stakeholders highlighted a series of complementary interventions required that relate to improvements in delivery mechanisms and the enabling environment (Table 5). Increasing the quality and diversity of germ plasm for native and exotic species was an important intervention across the three practices that stakeholders indicated could be achieved through expanding and strengthening existing community-based networks. Researchers also thought that the development of seed orchards and seed banks would reduce the reliance on external sourcing of germ plasm that is often driven by projects. This was a concept well received by local stakeholders. Sensitisation/awareness-raising activities were considered important for all three practices, to target not only beneficiaries, but also opinion leaders and customary chiefs. Capacity development, through increasing knowledge and technical skills, was also considered important, targeting not only specific interest groups, but also extension services, in general, who has received little agroforestry training and lacked expertise in collecting and handling native seeds. To scale up women's involvement in fruit tree production, training in fruit tree management and pest and disease control was identified as important, together with training in accounting and management skills that could underpin the development of collective action for enabling value addition. Expanding and strengthening collective action for improving the value chain, and thereby increasing returns, was important not only for fruits, but also for wood and honey from woodlots. Common enabling environment interventions revolved around the creation of a platform for sharing agroforestry knowledge and experience, for accessing credits and inputs, as well as for collective market action. Improving the very poor road infrastructure was also raised as an important factor to facilitate transport and market access. In the sphere of policy and institutional change, the major obstacles to adoption of agroforestry were identified as those related to tenure. Unclear and overlapping formal and customary land tenure and property rights indicated that stronger agrarian legislation and land 
Table 5. Interventions for improving the delivery mechanisms and enabling environment to scale up three agroforestry practices in the North Kivu province (bold X denote the interventions that apply to all three options).

\begin{tabular}{|c|c|c|c|c|}
\hline $\begin{array}{l}\text { Intervention } \\
\text { components }\end{array}$ & $\begin{array}{l}\text { Delivery mechanisms and } \\
\text { enabling environment }\end{array}$ & $\begin{array}{l}\text { Fruit } \\
\text { trees }\end{array}$ & $\begin{array}{l}\text { Fodder } \\
\text { banks }\end{array}$ & Woodlots \\
\hline Germ plasm & $\begin{array}{l}\text { Increase quality and diversity of seeds and seedlings } \\
\text { Initiate domestication of native species } \\
\text { Establish local seed banks } \\
\text { Establish seed orchards for local production } \\
\text { Promote grafting reproduction methods } \\
\text { Promote alternative propagation (direct seeding, cuttings) }\end{array}$ & $\begin{array}{l}\mathbf{X} \\
\mathbf{X} \\
\mathbf{X} \\
\mathbf{X} \\
\mathrm{X}\end{array}$ & $\begin{array}{l}\mathbf{X} \\
\mathbf{X} \\
\mathbf{X} \\
\mathbf{X}\end{array}$ & $\begin{array}{l}\mathbf{X} \\
\mathbf{X} \\
\mathbf{X} \\
\mathbf{X}\end{array}$ \\
\hline $\begin{array}{l}\text { Sensitisation - } \\
\text { awareness } \\
\text { raising }\end{array}$ & $\begin{array}{l}\text { Establish demonstration farms and experimental fields } \\
\text { Extension material in local languages } \\
\text { Farmer organisations on land tenure rules and rights } \\
\text { Religious confessions/opinion leaders on agroforestry planning } \\
\text { Local customary chiefs - on agroforestry planning } \\
\text { Herder groups agroforestry on zero-grazing systems } \\
\text { Nutrition (schools, market, radio theatre) }\end{array}$ & $\begin{array}{l}\mathbf{X} \\
\mathbf{X} \\
\mathbf{X} \\
\mathbf{X} \\
\mathbf{X}\end{array}$ & $\begin{array}{l}\mathbf{X} \\
\mathbf{X} \\
\mathbf{X} \\
\mathbf{X} \\
\mathbf{X} \\
\mathrm{X}\end{array}$ & $\begin{array}{l}\mathbf{X} \\
\mathbf{X} \\
\mathbf{X} \\
\mathbf{X} \\
\mathbf{X}\end{array}$ \\
\hline $\begin{array}{l}\text { Capacity build- } \\
\text { ing/knowledge }\end{array}$ & $\begin{array}{l}\text { Extension staff and farmer groups in seed collection of native species } \\
\text { Extension staff and farmer groups in seed handling and conservation } \\
\text { Local extension staff in fruit tree management } \\
\text { Women in fruit tree propagation and management } \\
\text { Women in fruit tree pest and disease control } \\
\text { Local extension staff in improved tree fodder management } \\
\text { Herders in improved tree fodder management (types, quantity, timing) } \\
\text { Beekeepers (Batwa included) in improved apiculture techniques } \\
\text { Women in fruit transformation techniques } \\
\text { Women in accounting and management skills }\end{array}$ & $\begin{array}{l}\mathbf{X} \\
\mathbf{X} \\
\mathrm{X} \\
\mathrm{X} \\
\mathrm{X}\end{array}$ & $\begin{array}{l}\mathbf{X} \\
\mathbf{X}\end{array}$ & $\begin{array}{l}\mathbf{X} \\
\mathbf{X}\end{array}$ \\
\hline Market & $\begin{array}{l}\text { Support collective action for improving access to markets } \\
\text { Market information systems } \\
\text { Developing efficient value chain for honey, fruits, timber, charcoal, } \\
\text { fodder } \\
\text { Improve market value of fruits through transformation } \\
\text { Developing efficient value chain for honey, fruits, timber, charcoal, } \\
\text { fodder } \\
\text { Link farmers to markets and businesses through fairs and market days }\end{array}$ & $\begin{array}{l}\mathbf{X} \\
\mathbf{X} \\
\mathbf{X} \\
\mathrm{X} \\
\mathrm{X}\end{array}$ & $\begin{array}{l}\mathbf{X} \\
\mathbf{X} \\
\mathbf{X}\end{array}$ & $\begin{array}{l}\mathbf{X} \\
\mathbf{X} \\
\mathbf{X}\end{array}$ \\
\hline $\begin{array}{l}\text { Networks - } \\
\text { platforms }\end{array}$ & $\begin{array}{l}\text { Create a multi-stakeholders agroforestry platform } \\
\text { Support access to credit schemes } \\
\text { Create groups for collective action based on selected commodities }\end{array}$ & $\begin{array}{l}\mathbf{X} \\
\mathbf{X} \\
\mathbf{X}\end{array}$ & $\begin{array}{l}\mathbf{X} \\
\mathbf{X} \\
\mathbf{X}\end{array}$ & $\begin{array}{l}\mathbf{X} \\
\mathbf{X} \\
\mathbf{X}\end{array}$ \\
\hline Infrastructure & $\begin{array}{l}\text { Build fruit selling points for collective sales } \\
\text { Road network }\end{array}$ & $\begin{array}{l}\mathrm{X} \\
\mathrm{X}\end{array}$ & & $\mathrm{X}$ \\
\hline $\begin{array}{l}\text { Policies-laws-- } \\
\quad \text { rules }\end{array}$ & $\begin{array}{l}\text { Reform of agrarian legislation } \\
\text { Reform of land tenure policy } \\
\text { Investment in agroforestry research } \\
\text { Investment in the rehabilitation of road network } \\
\text { Support for botanical gardens development and maintenance } \\
\text { Develop and implement a national seed policy } \\
\text { Cross sectoral programs should include agroforestry } \\
\text { Taxation policy on charcoal }\end{array}$ & $\begin{array}{l}\mathbf{X} \\
\mathbf{X} \\
\mathbf{X} \\
\mathrm{X} \\
\mathbf{X} \\
\mathrm{X} \\
\mathrm{X}\end{array}$ & $\begin{array}{l}\mathbf{X} \\
\mathbf{X} \\
\mathbf{X} \\
\mathbf{X} \\
\mathrm{X} \\
\mathrm{X}\end{array}$ & $\begin{array}{l}\mathbf{X} \\
\mathbf{X} \\
\mathbf{X} \\
\mathrm{X} \\
\mathbf{X}\end{array}$ \\
\hline
\end{tabular}


use planning would be required to foster cross-sectoral integration, enabling larger investments in agroforestry.

\section{DISCUSSION}

Several themes emerged from the results of using a structured multi-stakeholder agroforestry design process around which we have structured the discussion. The first was the contrast between the nature of current reforestation programs in the region and the potential for a much wider diversity of species and tree management options, tailored to the heterogeneity of the landscape and farmers' needs. The second was the importance of delivery mechanisms and the enabling environment for scaling up agroforestry, including supply of seeds and seedlings, and the development of markets and appropriate policies and institutions. At last, we reflect on the lessons learnt from applying a structured stakeholder approach that combined consideration of multiple knowledge systems with engaging multiple stakeholders to enable the co-design of agroforestry options.

\section{Tree diversity and social inclusion}

The dominant agroforestry interventions in the region had previously focused on promoting fast growing exotic species for the production of energy or timber in woodlots, largely dominated by the Eucalyptus genus and also including Acacia mearnsii and Senna siamea (both of which have the potential to be invasive) and to a lesser extent Grevillea robusta (LeJeune et al., 2013). The process of engaging with a range of local stakeholders, using a holistic landscape and farming systems approach (Sinclair, 1999), led to a rapid identification of a diverse set of locally relevant agroforestry practices, in various farm and landscape niches, and a list of more than 70 species, including 30 native trees not previously part of formal tree promotion efforts in the region, but locally known as useful for different contexts. This list was complemented by local knowledge acquisition, information from natural vegetation maps and market studies, leading to the development of a technical extension manual and a series of training materials covering 120 species (Smith Dumont et al., 2015).

The discussions of species suitability for different farm and landscape niches during knowledge acquisition and at the design workshops led to elicitation of a rich set of information about how to manage trees and their interactions with crops, livestock and human needs. This knowledge embraced the range of conditions across the province, rendered diverse because of altitudinal variation and varied social and economic context. These result in fine scale variation in agroecosystems, based around annual and perennial crops, mixed farming and dairy production. Key gaps in local knowledge were also identified, especially relating to tree propagation, consistent with findings more broadly (Lillesø et al., 2011).

Conventional approaches to tree promotion have focused on identifying a few, usually exotic, tree species through rapid participatory appraisal and ranking, aiming at consensus on priorities (Franzel et al., 1996), rather than embracing the diversity of needs and conditions that farmers experience (German et al., 2006). A potential 
drawback with promoting only a few species is that if this is successful it may result in reducing the biodiversity of landscapes and hence their resilience (Harvey et al., 2011). A number of recent studies in East Africa have shown that farmers, when deciding on tree retention and planting on their farms in less disrupted landscapes than those of North Kivu, have tended to embrace a diversity of species that contribute to landscape and livelihood resilience (Iiyama et al., 2016; Nyaga et al., 2015). Although tree planting is aiming to contribute to landscape restoration around protected areas, as is the case around the Virunga National Park, it is particularly important to promote a diversity of tree species that can contribute to biodiversity conservation at the same time as productivity and profitability of farming (Ashley et al., 2006).

This diversity of agroforestry options generated from stakeholder engagement, included species and practices that could benefit a much greater diversity of people than were previously reached by woodlots of exotic species, that tended to be adopted by male farmers with sufficiently large land holdings to be able to devote land exclusively to timber or charcoal production (LeJeune et al., 2013). Options identified during the stakeholder engagement process, included early maturing fruit tree species, with options to add value through processing into juice or jam, as well as fertilizer trees to improve soil fertility, favoured by women. Men from the indigenous Batwa community were interested in meliferous trees to support honey production from their bee-keeping enterprises. Tree species suitable for both windbreaks and fodder production were identified by livestock keepers as important for the extensive areas of pasture in the landscape and to support dairy production. The identification of options for a broader range of stakeholders derives specifically from the strategy of knowledge acquisition from different stakeholder groups, coupled with workshop sessions deliberately organised to give voice to otherwise marginalized people, who often lack agency in multi-stakeholder fora (Chomba et al., 2015). This was particularly effective in addressing issues important for women through having workshop groups focusing specifically on trees and gender, comprising all of the female participants. Greater inclusiveness in agroforestry options identified and promoted in an area is likely to lead to more effective scaling up because the range of options addresses needs of a higher proportion of the people living there (Coe et al., 2014; Franzel et al., 2001).

\section{Seed and seedling supply mechanisms}

Access to quality tree planting material for a diverse range of species was identified as a major barrier to the adoption of many of the agroforestry options considered relevant in North Kivu, a situation mirrored in many places across Africa (Nyoka et al., 2011). Despite recent efforts to develop locally sustainable tree seed and seedling supply systems, it remains common in Africa for the availability of tree planting material to be largely determined by government institutions and NGOs continuing to freely distribute a limited number of often exotic species that can be quickly accessed in large quantities by tree promotion initiatives (Brandi et al., 2007; DeFries et al. 2007). A major issue is that the same traits that make species good candidates for 
mass seed production also make them more susceptible to being invasive or aggressive, potentially posing threats to biodiversity (Ashley et al., 2006). Most donor-driven tree planting projects are governed by short-term targets specifying how many trees are to be planted, often with little consideration of which species these are, the quality of germ plasm used or its relevance to local conditions (Nyoka et al., 2011). The stakeholders involved in the design workshops underlined the relevance of a wide range of species, and they also stressed the need to move away from sole reliance on sourcing germ plasm through external projects, to develop locally owned seed orchards for native and exotic species, to domesticate native species and promote alternative modes of propagation (natural regeneration or vegetative propagation methods). They also identified key knowledge and skill gaps in the propagation of native tree species amongst both farmers and extension staff. This corroborates recent global reviews that have highlighted the importance of developing local sourcing of tree germ plasm coupled with market development, to ensure supply of quality tree seeds and seedlings, through fostering the growth of small seed and seedling production and distribution enterprises (Lillesø et al., 2011)

\section{Enabling environment: markets and the policy environment}

Despite the existence of important markets for numerous wood and non-wood products in North Kivu, a good understanding of how these markets operate is lacking and market development is heavily constrained by political uncertainty and weak governance (O’Donnell et al., 2015). It has been suggested that scaling up adoption of agroforestry practices requires strategies for promoting tree planting to be connected to interventions aiming to expand market opportunities for farmers, around diversified portfolios of high-value products (Russell and Franzel, 2004). Increasing the knowledge of farmers, technicians and rural advisory agents in processing of tree products was identified as an important capacity strengthening activity, required to foster value chain development for agroforestry products in North Kivu, with women specifically interested in processing fruit but constrained by the lack of access to micro-finance. A key realization from the stakeholder engagement process was that extension approaches would need to be tailored to different stakeholder groups, with a focus on gender and socioeconomic differences that determine gaps in knowledge and skills (Franzel et al., 2001). Combining market information with value chain interventions in production, harvest and post-harvest stages with institutional support for collective action, has been found critical for supporting enterprise development and commercialisation of agroforestry elsewhere in Africa (Gyau et al., 2014).

North Kivu faces particularly daunting challenges with respect to governance issues that for most agroforestry initiatives represent context, rather than presenting an opportunity to intervene. Depending on the size and scope of interventions possible, policy and institutional reform may either be an option, or represent context within which other technology, extension system and market options have to work (Coe et al., 2014). In North Kivu, weak and pluralistic governance mechanisms in a politically unstable region, prone to ethnic conflict, have been associated with land grabbing, a low level of public investment in infrastructure, and burdening taxation 
in an often corrupt environment, all of which hinder agricultural development and natural resource management (Vlassenroot and Huggins, 2005). Resulting lack of security in land tenure deters many farmers from investing in trees. Although this constrains what can be done to improve the enabling environment for agroforestry interventions, stakeholders identified possibilities to expand and strengthen farmer networks associated with sourcing germ plasm, as well as collective processing and marketing of agroforestry products. They also highlighted areas where the extension system could be improved through capacity strengthening as discussed above.

\section{Lessons from the structured stakeholder engagement process}

The structured stakeholder engagement has resulted in recommending a far more diverse set of options than were considered previously or that prioritization and ranking methods, which deliberately seek consensus on a few priority species, would be likely to elicit (Franzel et al., 1996). Prioritization, although also participatory, typically results in identifying fewer than ten tree species at the regional or even national levels, appropriate for focusing tree domestication efforts (Dawson et al., 2012) but not necessarily for identifying what trees and agroforestry practices to promote to farmers in any particular locality (Coe et al., 2014). There has been a long history of researcher-led participatory diagnosis and design in agroforestry (Raintree, 1987), but this has tended to lead to rich diversity of diagnoses but only a very restricted set of suggested interventions (Sinclair and Walker, 1999). The colearning process of involving stakeholders in conceptualizing tree planting through the identification of field, farm and landscape niches for different tree species and functions used here, resulted in a much wider diversity of agroforestry options than where researchers fit, a usually limited set of prescribed interventions to match a diagnosis. We found that the initial knowledge acquisition phase was critical for informing and enabling researchers to facilitate the stakeholder workshops. This was because talking with farmers and other stakeholders on their own turf, where they were more confident, enabled an understanding of what different stakeholders knew about trees and agroforestry to emerge (Sinclair and Walker, 1999), as well as their preferences and the constraints that they faced. By deliberately consulting different stakeholders, encompassing explicit consideration of gender, ethnicity, wealth and the different roles people played in the agricultural system (such as farmers, extension staff, development professionals, researchers and community leaders), a range of distinct perspectives were gathered that researchers used to structure the workshop sessions, for example, by including a group focusing on trees and gender that included all of the female participants, enhancing their agency and the importance accorded to their perspectives in the agroforestry options that emerged from the stakeholder engagement process.

So, the initial knowledge acquisition enabled researchers to set up effective stakeholder dialogue because many key issues were identified before the workshops, and the workshop sessions were then deliberately structured to address them. On reflection, we found evidence of changes in the knowledge and attitudes of stakeholders. One farmer indicated when evaluating the Goma workshop that he had 
been empowered through realizing that he knew as much about local agroforestry practices and requirements as researchers, and the head of a local NGO remarked at the Butembo workshop that 'this was the first meeting where scientists and farmers could interact, the approach was rich in learning and in giving and receiving'. The forest manager with the WWF ECOmakala project said after the Goma workshop that it had opened up our perspectives on tree planting, we realize we need to do things differently and adapt our approach to promote agroforestry and different species', whereas an extension agent for a local farmers' association remarked that 'I was not aware there were so many important native species we could promote and that agroforestry was about so many different practices'. Similarly, at the Butembo workshop a coordinator of an NGO said that 'I have been planting trees with ECOmakala since 2006 and wondering how we could develop agroforestry, now we know how to give better advice to our farmers'.

The combination of structured stakeholder engagement to design agroforestry options with the subsequent technical training that integrated local knowledge with global scientific expertise resulted in changes in knowledge and attitudes about tree planting amongst stakeholders including farmers, researchers, extension staff and development agencies. This is evidenced by the reflection workshop that took place a year and a half after the stakeholder design workshops. Several local communitybased organisations and regional NGOs currently working in partnership with WWF presented some of their achievements since the design workshops. They indicated changes in their practice, including promoting a broader range of tree species as detailed in the technical manual, including native species not previously promoted by either government extension systems or non-governmental organisations (NGOs) in the region. They also indicated that they were recommending a more diverse range of ways in which these tree species could be incorporated within fields and farming landscapes rather than focusing on woodlots (Smith Dumont and Bonhomme, 2016). The extent to which this results in changes in farmer behaviour and more diverse tree cover across the landscape is a key priority for subsequent impact evaluation. Experience from the Lake Tanganyika catchment, where similar approaches to engaging stakeholders in agroforestry design were followed in a development initiative, led to over 2 million trees being locally raised and planted in 2012, including 16 native species not previously promoted in the region (Marijnissen, 2013).

\section{CONCLUSION}

Our results demonstrate that consulting a broad range of stakeholders and sharing knowledge amongst them through facilitated workshops, resulted in a shift from the promotion of a handful of exotic tree species in woodlots, largely benefiting wealthier men, to recommendations for over 70 species, 30 of them native, across a wide range of field, farm and landscape niches. These options addressed the needs of women, various ethnic groups and different types of farmers, including those producing annual crops, perennial crops and livestock. Although the use of multiple stakeholder engagement and participatory processes are generally known to be 
effective bottom up approaches that increase learning, local ownership and adoption of new technologies (Akpo et al., 2014; Franzel et al., 2001), the novel aspect of this method stems from building on explicit acquisition of local knowledge, which was then used to facilitate a systematic consideration of trees at field, farm and landscape scales. This outlook on agroforestry resulted from the structuring of information around consideration of different options (technologies, market interventions and institutional reform), and the contexts for which they were relevant (covering ecological, economic, social and cultural factors). The options that were identified related as much to addressing key constraints to scaling up agroforestry in the enabling environment, including market, extension system and institutional interventions, as to technology options at field, farm and landscape scales.

Acknowledgements. This research was conducted under the project 'Forest and Climate change in the Congo' led by the Center for International Forestry Research (CIFOR) with funding from the Global Climate Change Alliance of the European Union and the CGIAR research programme on Forests, Trees and Agroforestry. We thank the World Wide Fund for Nature team in DRG and all the farmers and extension agents that contributed to building the knowledge about agroforestry. Two anonymous reviewers provided insightful comments on the initial manuscript.

\section{REFERENGES}

Akpo, E., Crane, T. A., Vissoh, P. V. and Tossou, R. C. (2014). Co-production of knowledge in multi-stakeholder processes: Analyzing Joint Experimentation as social learning. Journal of Agricultural Education and Extension 1-20. https://doi.org/10.1080/1389224X.2014.939201.

Ashley, R., Russell, D. and Swallow, B. (2006). The policy terrain in protected area landscapes: Challenges for agroforestry in integrated landscape conservation. Biodiversity \& Conservation 15(2):663-689.

Brandi, E., Lillesø, J.-P. B., Moestrup, S. and Kisera, H. K. (2007). Do organisations provide quality seed to smallholders?: A study on tree planting in Uganda, by NGOs and CBOs. In Development and Environment, No 8, 68. Hørsholm: Center for Skov, Landskabog Planlægning/Københavns Universitet, Denmark.

Chevalier, J. M. and Buckles, D. J. (2013). Participatory Action Research: Theory and Methods for Engaged Inquiry. UK: Routledge.

Chomba, S. W., Nathan, I., Minang, P. A. and Sinclair, F. (2015). Illusions of empowerment? Questioning policy and practice of community forestry in Kenya. Ecology and Society 20(3):2. https://doi.org/10.5751/ES-07741-200302.

Coe, R., Sinclair, F. and Barrios, E. (2014). Scaling up agroforestry requires research 'in'rather than 'for'development. Current Opinion in Environmental Sustainability 6:73-77.

Dawson, I., Harwood, C., Jamnadass, R. and Beniest, J. (eds.) (2012). Agroforestry Tree Domestication: A Primer, 148. Nairobi, Kenya: The World Agroforestry Centre.

DeFries, R., Hansen, A., Turner, B., Reid, R. and Liu, J. (2007). Land use change around protected areas: Management to balance human needs and ecological function. Ecological Applications 17(4):1031-1038.

Franzel, S., Coe, R., Cooper, P., Place, F. and Scherr, S. J. (2001). Assessing the adoption potential of agroforestry practices in sub-Saharan Africa. Agricultural Systems 69(1):37-62.

Franzel, S., Jaenicke, H. and Janssen, W. (1996). Choosing the Right Trees: Setting Priorities for Multipurpose Tree Improvement, 81. The Netherlands: The Hague, ISNAR.

German, L. A., Kidane, B. and Shemdoe, R. (2006). Social and environmental trade-offs in tree species selection: A methodology for identifying niche incompatibilities in agroforestry. Environment, Development and Sustainability $8(4): 535-552$.

Gilbert, J. (2013). Constitutionalism, ethnicity and minority rights in Africa: A legal appraisal from the Great Lakes region. International fournal of Constitutional Law 11(2):414 437. 
Gyau, A., Franzel, S., Chiatoh, M., Nimino, G. and Owusu, K. (2014). Collective action to improve market access for smallholder producers of agroforestry products: Key lessons learned with insights from Cameroon's experience. Current Opinion in Environmental Sustainability 6:68-72.

Harvey, C. A., Villanueva, C., Esquivel, H., Gomez, R., Ibrahim, M., Lopez, M., Martinez, J., Munoz, D., Restrepo, C., Saenz, J., Villacis, J. and Sinclair, F. L. (2011). Conservation value of dispersed tree cover threatened by pasture management. Forest Ecology and Management 261(10):1664-1674. http://www.sciencedirect.com/science/article/ pii/S03781 12710006638 .

Iiyama, M., Derero, A., Kelemu, K., Muthuri, C. W., Kinuthia, R., Ayenkulu, E., Kiptot, E., Hadgu, K., Mowo, J. and Sinclair, F. L. (2016). Understanding patterns of tree adoption on farms in semi-arid and sub-humid Ethiopia. Agroforestry Systems. http://link.springer.com/article/10.1007/s10457-016-9926-y.

Institut National de la Statistique (INS) (2015). Annuaire Statistique 2014, 560. République Démocratique du Congo: Ministère du Plan et Révolution de la Modernité.

Jayne, T. S., Chamberlain, J. and Headey, D. D. (2014). Land pressures, the evolution of farming systems, and development strategies in Africa: A synthesis. Food Policy 48:1-17.

Kiptot, E. and Franzel, S. (2012). Gender and agroforestry in Africa: A review of women's participation. Agroforestry Systems 84(1):35-58.

Lejeune, G., Ansay, F., Van Geit, M. and Lusenge, T. (2013). ECOmakala: Répondre à la Demande énergétique Pour Protéger les Forêts du Parc National des Virunga au Nord-Kìu (RDC) et Lutter Contre la Pauvreté, 36. Belgium: WWF.

Lillesø, J., Graudal, L., Moestrup, S., Kjær, E.D., Kindt, R., Mbora, A., Dawson, I., Muriuki, J., Ræbild, A. and Jamnadass, R. (2011). Innovation in input supply systems in smallholder agroforestry: Seed sources, supply chains and support systems. Agroforestry Systems 83(3):347-359.

Marijnissen, S. (2013). Lessons Learnt. Sustainable Catchment Management Interventions in the Uvira Territory, South Kivu Province, DRC, 73. GEF/UNDP. http://iwlearn.net/iw-projects/1017/reports/lessons-learnt-on-sustainablecatchment-management-interventions-in-the-uvira-territory-south-kivu-province-drc.

Mbow, C., van Noordwijk, M., Prabhu, R. and Simons, T. (2014). Knowledge gaps and research needs concerning agroforestry's contribution to sustainable development goals in Africa. Current Opinion in Environmental Sustainability 6:162-170.

Meijer, S. S., Catacutan, D., Ajayi, O. C., Sileshi, G. W. and Nieuwenhuis, M. (2015). The role of knowledge, attitudes and perceptions in the uptake of agricultural and agroforestry innovations among smallholder farmers in subSaharan Africa. International Fournal of Agricultural Sustainability 13(1):40-54.

Millennium Ecosystem Assessment (MA) (2005). Ecosystems and Human Well-Being: Synthesis, 155. Washington, DC: Island Press.

Nyaga, J., Barrios, E., Muthuri, C. W., Öborn, I., Matiru, V. and Sinclair, F. L. (2015). Evaluating factors influencing heterogeneity in agroforestry adoption and practices within smallholder farms in Rift Valley, Kenya. Agriculture, Ecosystems \& Environment, 212:106-118.

Nyoka, B. I., Mng'omba, S. A., Akinnifesi, F. K., Ajayi, O. C., Sileshi, G. and Jamnadass, R. (201 1). Agroforestry tree seed production and supply systems in Malawi. Small-Scale Forestry 10(4):419-434.

O'Donnell, M., Cook, A. and Magistro, J. (2015). Assessment of the DRC's agricultural market systems: Value chains in the North \& South Kivu and Katanga provinces. LEO Report \#16, USAID, Washington. 192.

Plumptre, A. J., Davenport, T. R., Behangana, M., Kityo, R., Eilu, G., Ssegawa, P. and Moyer, D. (2007). The biodiversity of the Albertine Rift. Biological Conservation 134(2):178-194.

Pollini, J. (2009). Agroforestry and the search for alternatives to slash-and-burn cultivation: From technological optimism to a political economy of deforestation. Agriculture, Ecosystems \& Environment 133(1):48-60.

Raintree, J. (1987). The state of the art of agroforestry diagnosis and design. Agroforestry Systems 5:219-250

Reubens, B., Moeremans, C., Poesen, J., Nyssen, J., Tewoldeberhan, S., Franzel, S. and Muys, B. (2011). Tree species selection for land rehabilitation in Ethiopia: From fragmented knowledge to an integrated multi-criteria decision approach. Agroforestry Systems 82(3):303-330.

Russell, D. and Franzel, S. (2004). Trees of prosperity: Agroforestry, markets and the African smallholder. In New Vistas in Agroforestry, 345-355. Springer.

Sinclair, F. L. (1999). A general classification of agroforestry practice. Agroforestry Systems 46(2):161-180.

Sinclair, F. L. and Walker, D. H. (1999). A utilitarian approach to the incorporation of local knowledge in agroforestry research and extension. In Agroforestry in Sustainable Agricultural Systems, 245-275 (Eds L. E. Buck, J. P. Lassoie and E. C. M. Fernandes). New York: Lewis Publishers.

Smith Dumont, E. and Bonhomme, S. (2016). Rapport de l'atelier sur la pérennisation de l'agroforesterie en province du Nord-Kivu, 51. http://www.worldagroforestry.org/output/north-kivu-report-workshop-drc. 
Smith Dumont, E., Bonhomme, S. and Sinclair, F. L. (2015). Guide Technique d'agroforesterie Pour la Sélection et la Gestion des Arbres au Nord-Kivu, 130. Nairobi, Kenya: RDC. World Agroforestry Centre.

Vlassenroot, K. and Huggins, C. (2005). Land, migration and conflict in eastern DRC. In From the Ground Up: Land Rights, Conflict and Peace in Sub-Saharan Africa, 115-194 (Eds C. Huggins and J. Clover). Nairobi/Pretoria: African Centre for Technology Studies Press/Institute for Security Studies.

Appendix 1: List of the 71 species identified during the participatory agroforestry workshops with their origin $(\mathrm{e}=$ exotic; $\mathrm{n}=$ native).

\begin{tabular}{|c|c|c|c|}
\hline Botanical name & Origin & Botanical name & Origin \\
\hline Acacia mearnsii & $\mathrm{e}$ & Maesa lanceolata & $\mathrm{n}$ \\
\hline Acrocarpus fraxinifolius & $\mathrm{e}$ & Maesopsis eminï & $\mathrm{n}$ \\
\hline Albizia gummifera & $\mathrm{n}$ & Mangifera indica & $\mathrm{e}$ \\
\hline Annona muricata & $\mathrm{e}$ & Markhamia lutea & $\mathrm{n}$ \\
\hline Averrhoa carambola & $\mathrm{e}$ & Milicia excelsa & $\mathrm{n}$ \\
\hline Azadirachta indica & $\mathrm{e}$ & Morus alba & $\mathrm{n}$ \\
\hline Bambusa vulgaris & $\mathrm{e}$ & Coccinia grandis & $\mathrm{n}$ \\
\hline Cajanus cajan & $\mathrm{e}$ & Moringa oleifera & $\mathrm{e}$ \\
\hline Calliandra calothyrsus & $\mathrm{e}$ & Myrianthus arboreus & $\mathrm{n}$ \\
\hline Carica papaya & $\mathrm{e}$ & Olea africana & $\mathrm{n}$ \\
\hline Casuarina equisetifolia & $\mathrm{e}$ & Passiflora edulis & $\mathrm{e}$ \\
\hline Cedrela serrulata & $\mathrm{e}$ & Passiflora quadrangularis & $\mathrm{e}$ \\
\hline Citrus reticulata & $\mathrm{e}$ & Pennisetum spp & $\mathrm{n}$ \\
\hline Citrus limon & $\mathrm{e}$ & Persea americana & $\mathrm{e}$ \\
\hline Citrus sinensis & $\mathrm{e}$ & Piper guineense & $\mathrm{n}$ \\
\hline Coffea arabica & $\mathrm{e}$ & Podocarpus falcatus & $\mathrm{n}$ \\
\hline Cola nitida & $\mathrm{n}$ & Malus domestica & e \\
\hline Cordia abyssinica & $\mathrm{n}$ & Prunus africana & $\mathrm{n}$ \\
\hline Croton megalocarpus & $\mathrm{n}$ & Psidium guajava & e \\
\hline Cupressus lusitanica & $\mathrm{e}$ & Ricinus communis & $\mathrm{n}$ \\
\hline Cyphomandra betacea & $\mathrm{e}$ & Senna siamea & $\mathrm{e}$ \\
\hline Datura arborea & $\mathrm{e}$ & Senna spectabilis & $\mathrm{e}$ \\
\hline Dracaena cf. arborea & $\mathrm{n}$ & Sesbania sesban & $\mathrm{n}$ \\
\hline Entandrophragma excelsum & $\mathrm{n}$ & Sinarundanaria alpina & $\mathrm{n}$ \\
\hline Eriobotrya japonica & $\mathrm{e}$ & Spathodea campanulata & $\mathrm{n}$ \\
\hline Erythrina abyssinica & $\mathrm{n}$ & Syzygium guineense & $\mathrm{n}$ \\
\hline Eucalyptus citriodora & $\mathrm{e}$ & Syzygium malaccense & $\mathrm{e}$ \\
\hline Eucalyptus grandis & $\mathrm{e}$ & Tephrosia vogelii & $\mathrm{e}$ \\
\hline Ficus thonningii & $\mathrm{n}$ & Terminalia superba & $\mathrm{e}$ \\
\hline Ficus vallis-choudae & $\mathrm{n}$ & Tetradenia riparia & $\mathrm{n}$ \\
\hline Flemingia macrophylla & $\mathrm{e}$ & Tithonia diversifolia & $\mathrm{e}$ \\
\hline Gliricidia sepium & $\mathrm{e}$ & Urena lobata & $\mathrm{n}$ \\
\hline Grevillea robusta & $\mathrm{e}$ & Vernonia amygdalina & $\mathrm{n}$ \\
\hline Jatropha curcas & $\mathrm{e}$ & & \\
\hline Eremospatha haulevilleana & $\mathrm{n}$ & & \\
\hline Kigelia africana & $\mathrm{n}$ & & \\
\hline Laurus nobilis & $\mathrm{e}$ & & \\
\hline Leucaena leucocephala & $\mathrm{e}$ & & \\
\hline
\end{tabular}

